\title{
Eleanor Roosevelt, the United Nations and the Role of Radio Communications
}

\author{
By Anya Luscombe *
}

\begin{abstract}
Eleanor Roosevelt communicated with the public through a variety of media, both before, during and following her time in the White House. In 1946 she became part of the US delegation to the newly formed United Nations and she used newspaper columns, speeches and radio broadcasts to converse with citizens about the importance of the UN. This paper focuses on some of her radio performances of the early 1950s, both in the USA and in Europe. Despite increasing competition from television in the 1950s, radio still played a vital role in reaching mass audiences. Through rhetorical analysis, this paper seeks to establish how Mrs. Roosevelt addressed her audiences and how she educated them about the United Nations. Furthermore, it will examine the reactions to her broadcasts. The aim is to study the way radio was used to encourage listeners to become active citizens and how Eleanor Roosevelt, as a "public diplomat", was uniquely placed to use the power of the media.
\end{abstract}

Keywords: Eleanor Roosevelt, radio history, United Nations

\section{Introduction}

In 1951 as a political freeze settled over Europe, the Voice of America (VOA) turned to Eleanor Roosevelt for help. The head of the VOA's French desk, Fernande Auberjonois, asked the "First Lady of the World", to broadcast a weekly commentary in French as "a spokesman for peace and freedom" (Gardner, 1952). Mrs. Roosevelt agreed, as this would give her the opportunity to reach directly into the homes of fifteen million listeners to explain the significance of the United Nations, the institution for which she had been a US delegate for nearly six years and where she - as chair of the Human Rights Commission - had successfully drawn up the Universal Declaration of Human Rights in December 1948. It was not the first time that Mrs. Roosevelt appeared on radio. Indeed, she had been a radio pioneer, broadcasting as early as $1925 .^{1}$ In the 1930 s and 40 s she was frequently on the airwaves earning as much as the highest-paid radio stars (Belgrade, 2001). When her husband President Franklin Delano Roosevelt died in April 1945, Eleanor Roosevelt had thought she would no longer fulfil a public function (Black, 1996). However, in December of that year, FDR's successor Harry Truman asked her to become one of the US delegates to the newly formed United Nations. Although she initially hesitated, her desire to see nations work together to achieve lasting peace persuaded her to take on the function. "She quickly adapted to her new role, emerging at the first meeting the UN General

\footnotetext{
${ }^{*}$ Associate Professor, University College Roosevelt (Utrecht University), The Netherlands.

${ }^{1}$ In her radio debut she appeared on behalf of the women's City Club of New York (WiesenCook, 1992).
} 
Assembly as an international stateswoman" (Task Force, 2008). During her time as a delegate she frequently used the media ${ }^{1}$, including radio, to outline the workings of the UN and discuss the positions adopted by member countries on a host of issues, such as the status of refugees, the Korean War, and nuclear (dis)armament. Examples of programs in which the UN is the focus (accessible in the FDR Library, Hyde Park) are shown below:

\begin{tabular}{|c|c|c|c|}
\hline 1948 & Oct. 20 & $\begin{array}{l}\text { In observance of United Nations Week, NBC presents: } \\
\text { "What's Right with the UN-Human Rights under the UN." } \\
\text { Transcribed earlier in Paris for this presentation (NBC). }\end{array}$ & $75-8: 17$ \\
\hline 1948 & Oct. 31 & $\begin{array}{l}\text { Brief segment from Eleanor \& Anna Roosevelt program. Mrs. } \\
\text { Roosevelt interviewing Secretary General Lee of the United } \\
\text { Nations. The United Nations will have permanent headquarters } \\
\text { now being built in New York City. Asked about the progress of the } \\
\text { United Nations, Secretary General Lee states that the United } \\
\text { Nations is the greatest force for peace and against war in the world } \\
\text { today. }\end{array}$ & $80-5(1)$ \\
\hline 1949 & Oct. 24 & $\begin{array}{c}\text { Mrs. Roosevelt's appearance on Barbara Welles radio } \\
\text { program "Listen Ladies". Subject: Women's role in success of } \\
\text { the United Nations. WOR Mutual radio (5 min). Mrs. Roosevelt } \\
\text { commented on the fact that the committees in the United Nation in } \\
\text { which the Universal Declaration was considered, contained a great } \\
\text { number of women and that they had a great affect on the } \\
\text { humanities and social issues that arose. }\end{array}$ & $51-65: 5$ \\
\hline 1949 & Dec. 23 & $\begin{array}{c}\text { Interviewed on program "United Nations with Dwight Cooke." } \\
\text { Recorded by UN radio on Oct. 24, 1949. Recording by Empire } \\
\text { Broadcasting Corp, New York, NY. The interview took place at } \\
\text { Lake Success, New York. Mr. Cooke begins with a skeptical look } \\
\text { of the purpose of the United Nations. }\end{array}$ & $51-65: 3$ \\
\hline 1951 & Jan. 31 & $\begin{array}{l}\text { Program } 81 \text { "The Eleanor Roosevelt Program." Guest, } \\
\text { William Lawrence, author of 'Hell Bomb." ... Also a listener } \\
\text { writes, asking Mrs. Roosevelt if she believes in the effectiveness of } \\
\text { the United Nations which begins a discussion with Elliott } \\
\text { regarding communist China and her relations with the United } \\
\text { Nations. }\end{array}$ & 72-30(81) \\
\hline 1951 & Mar. 26 & $\begin{array}{l}\text { Program } 119 \text { "The Eleanor Roosevelt Program." Guest, } \\
\text { Ambassador Ernest A. Gross, Deputy Representative of the } \\
\text { United States to the United Nations. Elliot reads... Mrs. } \\
\text { Roosevelt introduces Ambassador Gross as being a member of the } \\
\text { Security Counsel of the United Nations. They speak of criticism of } \\
\text { the United Nations for not being unable to meet the threat of large } \\
\text { scale aggression between nations, and the effectiveness of the } \\
\text { United Nations. The Ambassador describes the efforts of the } \\
\text { United Nations to find a peaceful solution to the Korean } \\
\text { "question". }\end{array}$ & $72-30(119)$ \\
\hline
\end{tabular}

\footnotetext{
${ }^{1}$ Mrs. Roosevelt was a prolific writer - she wrote 27 books and thousands of magazine articles and newspaper columns, the best-known of which is "My Day" which she penned from 19351962. She also wrote speeches, gave lectures and appeared on television.
} 
This paper focuses on two of Mrs. Roosevelt's radio performances in 1951. Using rhetorical analysis to examine an episode of the Eleanor Roosevelt Program for US domestic audiences and a commentary for the $\mathrm{VOA}^{1}$ for primarily European audiences, the paper aims to describe how Eleanor Roosevelt encouraged her listeners to take an active interest in world issues and understand the role which she felt the United Nations could play during the strained times of the Cold War. Although the VOA broadcasts were delivered in French, here I will use the English translation (Press Release No. 1295, $1951)^{2}$.

Rhetoric is both about content and form of discourse, i.e. about what is communicated and how it is communicated. While there are many aspects one could focus on in a rhetorical analysis, this paper will concentrate on the three elements of Kairos, Audience and Decorum, which according to the Silva Rhetoricae of Brigham Young University "serve as a compass, even among the larger terms ("trees") in the forest of rhetoric" (Silva Rhetoricae). Kairos means the opportune moment, i.e. considers the place and time that the discourse happened; knowledge of who the Audience is and how it responds is crucial for discourse to be persuasive; Decorum relates to the level of style adopted by the speaker or writer and includes considerations of rhetorical distance and the use of style figures.

\section{Kairos}

While the USA and USSR had combined forces to defeat Nazi Germany, distrust between the two power blocs had already set in during World War II. "Soviet pressure in the Mediterranean and the Middle East, the breakdown of Four Power control in Germany [the Berlin Blockade] ... and the Sovietsponsored Prague Coup in early 1948 ... hardened policies on both sides" (Creswell, 2002, p. 23). The USA and its western allies signed the North Atlantic Treaty Organization (NATO) in April 1949 and by 1951 the Iron Curtain was well and truly drawn shut between West and Eastern Europe. In the USA fears of communism were rife. In February 1950 Senator Joseph McCarthy had claimed that "the State Department harbors a nest of Communists and Communist sympathizers who are helping to shape our foreign policy" (US Senate as cited in History Matters). The House UnAmerican Activities Committee meanwhile was aggressively pursuing citizens and organizations with alleged Communist sympathies. The USA was experiencing a consumer boom while most of Europe was economically still very fragile. France, the venue of the third session of the UN General

\footnotetext{
${ }^{1}$ The commentaries were broadcast both over the French National Network to listeners in France and to other countries through the VOA; when referring to the "VOA broadcast/ commentary" in this paper, I do not distinguish between the two.

2 Although it would be interesting to include a discussion of the auditory element of the broadcasts, space here is too limited.
} 
Assembly, was also strategically vulnerable and was extremely concerned that the Soviet Union might wish to invade the region (Creswell, 2002).

The Voice of America had started broadcasting in early 1942 as part of the Foreign Information Service's role to counter Nazi propaganda. When the Second World War ended, US politicians were not convinced of the need for the international radio service and obtaining funding was difficult. By 1948, however, with Cold War tensions rising and increased jamming of US radio signals by the Soviet Union, Congress was persuaded to invest more in the VOA (Cull, 2008; Pirsein, 1979). Despite increasing competition from television, radio still played a vital role in reaching mass audiences in the 1950s: 95.7\% US households owned a radio (as cited in Craig, 2009, p. 81). Indeed, according to Rothenbuhler and McCourt (2002), in the early part of the Cold War radio "provid[ed] new venues for expression of regional, class, and ethnic identities, radio played an instrumental role in a series of major transformations, if not revolutions, in American culture" (p. 368). In France radio was significantly more important than television during the 1950s; figures show that even in 1961 less than $20 \%$ of households had a television set whereas $80 \%$ owned a radio (Kuhn, 1995, p. 78).

Eleanor Roosevelt had been a social activist, campaigning for political, civil, workers' and women's rights for many decades. In 1946 when she first became a delegate to the UN, she had been placed in Committee Three that dealt with humanitarian, social and cultural concerns. This was the committee that considered the thorny issue of the repatriation of political refugees in Europe. As chair of the Human Rights Commission charged with drafting the Universal Declaration of Human Rights, she worked sixteen-hour days (Black, 2003). The Declaration was adopted by the General Assembly in December 1948. In terms of Kairos, 1950 was the opportune moment for Eleanor Roosevelt, as an established and respected international public diplomat, to use radio to educate listeners both at home and abroad about the role of the United Nations and the importance of nations working together to bring about peace and human rights.

\section{Audience}

The Eleanor Roosevelt Program on WNBC comprised 233 episodes which aired from October 11, 1950 until August 31, 1951. The 45-minute program went out every day of the week at $12.30 \mathrm{New}$ York time $^{1}$ and was usually broadcast from Mrs. Roosevelt's living room at the Park Sheraton hotel, although some special programs were recorded abroad. Subjects were mainly serious such as the United Nations, the Korean War, Communism and social problems, but also included culture (e.g. interviews with actors Gertrude Lawrence, John Steinbeck and Maurice Evans), and lighthearted topics such as baseball, Christmas traditions and Fala, Mrs. Roosevelt's dog. Daytime radio programming was aimed at a female audience and certainly in the first episode

\footnotetext{
${ }^{1}$ It was broadcast over another 20 radio stations across the US (Wamboldt, 1952).
} 
Mrs. Roosevelt's guest, comedian Fred Allen reinforces the impression that the former first lady's audience would predominantly consist of women listeners when he says "You are a woman and much better at telling women". Each episode usually followed the same format: Elliott Roosevelt would read out a letter from a listener (in the majority of cases from women listeners) in which his mother was asked about her opinion or asked to explain a particular issue. Then mother and son would discuss the issue further, after which Eleanor would interview one or more guests. The audience distribution is not known, but the final program of the series mentions WNBC audience ratings showing this was the most listened to program in all of New York at least. In that same program, Eleanor Roosevelt says to Elliott that her latest postbag suggested that listeners had got a great deal out of the program. "I was quite pleased [...] it had cleared things up for them".

The commentaries for the French National Network in November 1951February 1952 could also be heard in Belgium, Switzerland, Eastern Europe and North Africa through the facilities of the Voice of America (Press Release No. 1295, 1951). They were broadcast in French on Sunday evening 8 p.m. Paris time. According to a New York Times article by Richard Gardner from the time, the head of the VOA's French service, Fernande Auberjonois had thought that Mrs. Roosevelt was the "only logical choice ... for [the person who could] establish a link between America's UN delegation in Paris and the French public" (Gardner, 1952). In the first of the commentaries, Mrs. Roosevelt addresses this audience by saying: "I think that what you want to know-especially you the women of post-war Europe ...". However, letters reacting to the broadcasts ${ }^{1}$ show as many letters from men as from women listeners (Listeners' Reactions, 1951).

\section{Reactions}

A survey of reactions to Mrs. Roosevelt's VOA broadcasts, dated January 5, 1952, says "approximately two thirds of the letters emanate from listeners with a relative modest cultural background and whose standard of living appears to be low" (Memorandum). Auberjonois divided the reactions to Mrs. Roosevelt's talks into four types:

1. "violent criticism and threats" from Communists, e.g.: "We, the workers of France do not want your atom bombs..."

"Poor woman, you are being led by the nose and you are doing the dirty work of the trusts."

2. praise and encouragement, e.g.:

From Vannes: "With fervor and deep emotion we have listened to your warm, persuasive voice. You are where you belong, at the Palais de Chaillot where the fate of peace is being debated ... I wish I could come to Paris to listen to you and to see you ... ."

\footnotetext{
${ }^{1}$ Available in the Eleanor Roosevelt UN correspondence files (in the FDR library in Hyde Park, New York and the Roosevelt Study Center in Middelburg, the Netherlands).
} 
(man from Douai): "We are grateful to you for your efforts on behalf of world peace. The United States could not find a better spokesman in the UN."

3. skeptical approach on the part of Frenchmen who feel Human Rights are not respected in the US, e.g.:

"When you speak of Human rights and of respect of the individual, do you include the negroes too?" (From Lagnieu, AIN). PS: "I am not a negro."

4. "requests from the underprivileged for financial assistance."

(Memorandum, 1952)

The reactions to the VOA show a similar pattern to those which Mrs. Roosevelt had received in response to broadcasts in the USA in previous decades. There were those who adored her and others who felt she should keep her nose out of politics. In the case of the VOA, as Mrs. Roosevelt was representing the US delegation to the United Nations, there were similarly listeners that complained that the US ought to keep its nose out of France's business. Nevertheless, on the whole the broadcasts were viewed as a great success by the VOA as a means to reach its intended audiences and soon Mrs. Roosevelt was asked to record messages in Italian, Spanish and German.

\section{Decorum/Style}

The style of a discourse can broadly be divided into plain, middle and grand, with increasing amounts of ornament. According to Cicero it requires judgment and skill on the part of the rhetor to determine which style (or combination of styles) is appropriate, taking into account the subject, audience and speaker's character. The effectiveness of a speaker's persuasive appeals (logos-logical argumentation; ethos-character; pathos-emotion) are heavily influenced by the style the speaker chooses to adopt. Style in turn, is visible through an analysis of the rhetorical distance in a text and the presence of style figures ${ }^{1}$.

There are different genres of radio broadcasts, but it is often taken that radio is a more intimate medium than print or television (Crisell, 1994) or online. The distance between the presenter and the listener, therefore, is likely to be small. Indeed, Mrs. Roosevelt often appears chatty. In both the NBC and VOA program she uses the first person and the direct mode of address. The programs examined here are conversations, interviews and commentaries, in which the attitude of the presenter will be more evident. More attitude (i.e. involvement in the issue) equates to a smaller rhetorical distance between presenter and audience (Crowley and Hawhee, 2012, p. 286). This would be very different in, for example, radio news where the tone is more neutral or in a radio play in which different fictional characters would feature. The next two

\footnotetext{
${ }^{1}$ This umbrella term will be used to denote figures of speech, figures of thought and tropes.
} 
sections will take a closer look at episode 134 (April 16, 1951) of The Eleanor Roosevelt Program - one of the many in which the issue of the United Nations comes up - and the first of her weekly "talks" for the French service, broadcast in November 18, 1951.

\section{The Eleanor Roosevelt Program, NBC, Episode 134}

Short excerpts from the transcriptions of this program have been chosen as examples where the subject of the United Nations is treated. In this case, the $\mathrm{UN}$ is dealt with because a listener asks about it (compare for example episode 160 of May 22, 1951 in which the UN is covered because Mrs. Roosevelt interviews Dr. Charles Malik, the new chair of the Human Rights Commission). Episode 134 on April 16, 1951 starts, as do all the programs, convivially.

How do you do? This is Eleanor Roosevelt speaking (.) it gives me great pleasure to visit with you as I do each day at this time from my living room atop the Park Sheraton hotel overlooking New York. I'm grateful for the many encouraging letters you send me and most happy that you find my guests both informative and entertaining as I do. Now my son Elliott who assists me on these programs will speak to you.

Elliot: $\quad$ Yes I will mother thank you (.) Today's guest Mr. Maurice Evans has brought Shakespearean plays to life for many people and many places but his role on today's program will be strictly Mr. Evans playing himself. Mrs. Roosevelt will introduce him a little later on in the program but first we're going to look over the mail and also here a message from the sponsors who make this recorded program possible.

(pause)

The use of the grammatical first-person "as I do", "I'm grateful", the reference to her living room as well as the introduction to her son Elliott, convey a feeling of domesticity, of being similar to those who are listening in their homes to the radio. The closeness of mother and son and the listener is further amplified in Elliott's address to "Mother". She appears delighted to answer the question from a Mrs. Rosengarten to help both her and other listeners "learn" about the United Nations, even if, as Elliott says, "I know that we've done this on the program before":

Elliot: $\quad$ Mother today I have a request from Mrs.Tony Rosengarten of Point Pleasant Pennsylvania (.) she says she wants to learn much more from you about the United Nations and especially about the different commissions, what is done and what could have been done uh she asks if she's wrong in her impression that our Congress very unfortunately is hampering the work of these commission.

Eleanor: No I don't think that uh directly our congress at present is hampering the work uhm you have uh of course you have to get appropriations uh from our congress so that we can carry a little more than our share in each um activity and sometimes they're not very anxious to make those appropriations but so far uh except for the fact that 
last year they would not appropriate the last fifteen million for the children's fund because they didn't feel that it was uhm uhm a proper uh properly set up.

Elliot: Yes (.) well now do you think you could take a little time this morning to to uh list again the various commissions that there are I know that we've done this on the program before but a great many people write in wanting more and more information.

$[\ldots]$

Mrs. Roosevelt then goes on to list a great number of committees, almost in a rambling style and Elliott interrupts on several occasions, trying to get her to focus. Eleanor Roosevelt is clearly comfortable enough to admit that she is not an expert on all matters relating to the UN "Oh, I don't know", adding to the listener's feeling that she is simply visiting Mrs. Roosevelt's home and listening into a conversation by mother and son, not scripted but full of false beginnings and vocalized pauses.

Elliot: Well now you are the chairman of the human rights commission. What is that a subsidiary of?

Eleanor: Economic and social council, it's appointed directly under them and also there is a commission on the status of women of which the United States is a member.

Eliot: $\quad \mathbf{H m h m}$ those are specialized again but the human rights commission.

Eleanor: Well they are not specialized agencies, they are direct commissions under the economic and social council and they don't have separate budget as their budget is in the United Nations budget.

Elliot: $\quad$ I see well now uh (.) these var what other commissions are there that of what of for instance comes under the security council?

Eleanor: Oh I don't know.

Elliot: $\quad$ Joint chiefs of staff and military?

Eleanor: The joint chiefs of staff are the only things I can think the atomic energy commission maybe uhm a separate one under the security council.

As it is a conversation, rather than a direct address, the style is plain, devoid of ornament.

\section{First Weekly Talk, French Service/VOA, November 18, 1951}

Mrs. Roosevelt's commentary for the VOA can be considered to employ a middle style. "Every kind of ornament in speaking is suitable to this style; and in this kind of oratory there is a great deal of sweetness" (Cicero, v. 28). Again, she uses the grammatical first person throughout. The first four paragraphs beginning with "I" make it very clear to the audience that this "talk" 
signifies her opinion: "I am speaking to you today ... I have been asked to ... I don't want to spend ... I think that what ....".

The use of the first-person pronoun "we" usually refers to the US, in particular the US Delegation to the General Assembly:

I have been asked to tell you, from time to time, what I think of the work we are doing here and why we, of the United States Delegation, believe that these meetings are so very important.

...That is why we have come to Paris, to work at building peace.

...We are firmly convinced that an agreement is possible.

...In America we call this a slogan.

However, there are a few instances in which the "we" is more inclusive:

If it were so we would have had peace long ago.

The Secretary of State pointed out - and we must not forget it -

The second person pronoun, you, is used for direct address to the listener. Note in particular the use of the adverbial "especially":

I think that what you want to know - especially you the women of postwar Europe - is whether you shall be able, tomorrow, to tell your children, that peace is, at long last, a reality. For it isn't enough to talk about peace. One must believe in it. And it isn't enough to believe in it. One must work at it.

The use of the first and second person pronouns lowers the rhetorical distance between Mrs. Roosevelt and her audience. In addition, there are several style figures which provide "sweetness". The first most prominent one is the climax in the abstract above (italicized): talk, believe, work. These four sentences also show parallelism - balanced clauses - and epiphora (repetition of "it" - which refers to peace - at the end of the three sentences). Parallelism is also evident in the three successive phrases:

from the arid soil of human misery, among the shambles of war, in the cold shade of despair.

The most vivid and effective style figure in this particular talk, however, is the metaphor comparing peace to a vulnerable plant, which Eleanor Roosevelt employs to make the abstract concept of peace clearer to her listeners: 
I believe that peace is something you must cultivate with great care and tenderness. Like certain delicate plants and flowers peace needs warmth and love. Cynicism and abuse will harm it. However, if those who wish it well do something to protect peace, it can and it will grow.

The verbs that accompany the metaphor "cultivate, protect, grow" add to its persuasive power and imply that the US and the people of France (and its neigbouring countries and territories) and the Soviet Union can help by positive action and tending the garden. The metaphor is further extended (allegory) when she contrasts delicate plants with weeds and talks about her personal experience of gardening:

A few years ago, immediately after World War II, we disarmed so speedily that we soon found ourselves defenseless. Some were saying then, that peace can grow anywhere, among the rocks and in the sand, like weeds.

Like most Americans, I have a garden. I know that nothing can really grow if the soil has not been cultivated, ploughed, and fertilized. Nothing grows in a poor soil. After the war, Europe's soil was poor. We know then that a lasting peace could not grow from the acrid soil of human misery, among the shambles of war, in the cold shade of despair.

Today nothing is perfect. You know this as well as I do. But we are firmly convinced that an agreement is possible if all nations will approach this task with good faith and a will to peace.

She urges listeners to be hopeful about the future, encourages them to help with the cultivation of the barren ground and achieve real, long-lasting beautiful peace, not weeds, in a new Europe where there can be an abundance of light and produce, following the arid years of war and deprivation. None of this will be possible, however, without hard work on the part of everyone governments, diplomats and listeners - thereby reinforcing the earlier climax "one must talk about it, believe in it, work at it".

\section{Conclusions}

In the early 1950s Eleanor Roosevelt had enormous situated ethos in the US and in Europe. Fondly remembered as a First Lady who really cared about people, she was the widow of the highly respected former President Franklin Delano Roosevelt without whom Europe may not have fought off the Nazis, and now she was "First Lady of the World", the stateswoman who had managed to get countries around the world to agree on a set of universal human rights. As Gardner (1952) says, Mrs. Roosevelt did "more to create goodwill for the United States in Western Europe than ... any other American". 
Perfectly attuned to take advantage of the kairotic moment for her broadcasts, using her situated ethos and addressing the audience appropriately, she could through her adept use of radio build a firm relationship with her listeners. As a public diplomat both at home and abroad, she was uniquely placed to use the power of the media to educate audiences about causes she believed in and encourage them to take an active interest in politics and international affairs. Radio, such a vital means of communication in the early part of the Cold War, gave her the opportunity to address her public in their own homes: they could have their questions answered, join in the conversation and hear Mrs. Roosevelt speak to them directly. The right moment, the importance of the message, the image she portrayed and the rhetorical distance she created by her intimate and stylish language, helped to - as listener Alexandre Berardo from Marseille said - "dispel [people's] doubt":

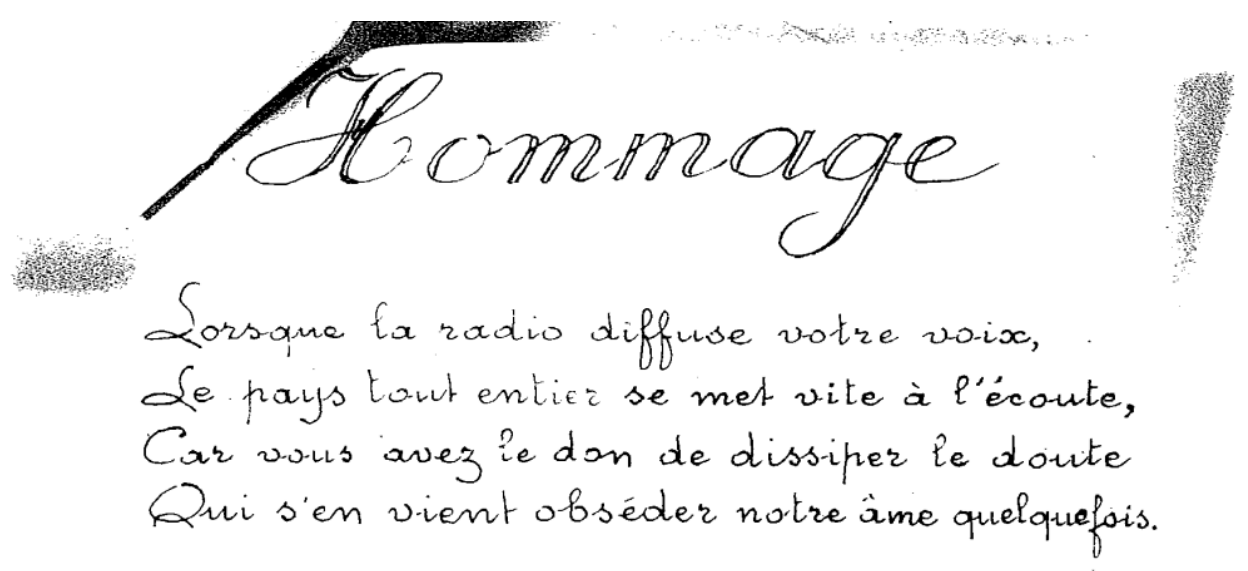

When the radio broadcasts your voice, The whole country hastens to hear your words.

Because you have the gift to dispel doubt

That sometimes haunts our soul.

(Hommage, 1952)

\section{References}

Belgrade, P. (2001). Radio Broadcasts. In M. Beasley, H. Shulman and H. Beasley (Eds.) The Eleanor Roosevelt Encyclopedia. Westport, Connecticut, London: Greenwood Press.

Black, A. (1996). Casting Her Own Shadow. New York, Chichester: Columbia University Press.

Black, A. (2003). Introduction. The Papers of Eleanor Roosevelt, 1945-1962. Part 2: United Nations Human Rights Commission Correspondence and Publications. Bethesda, MD: Congressional Information Service.

Cicero. (n.d.) Marcus Tullius Cicero. The Orator. Retrieved from http://www.egs.edu/ library/cicero/articles/the-orator/. [Accessed: 15 March 2015]

Crisell, A. (1994). Understanding Radio ( $2^{\text {nd }}$ ed.). London: Routledge. 
Craig, S. (2009). Out of the Dark. A History of Radio and Rural America. Tuscaloosa: The University of Alabama Press.

Creswell, M. (2002). "With a Little Help from our Friends": How France Secured an Anglo-American Continental Commitment, 1945-54. Cold War History, 3(1), 128.

Crowley, S. and Hawhee D. (2012). Ancient Rhetorics for Contemporary Students. $\left(5^{\text {th }}\right.$ edn.). Boston: Pearson.

Cull, N. (2008). The Cold War and the United States Information Agency. American Propaganda and Public Diplomacy, 1945-1989. New York: Cambridge University Press.

Eleanor Roosevelt Program (1950-1951). New York: NBC. [Radio Series]. Middelburg: Roosevelt Study Center Collection. Program 134, April 16, 1951 and Program 233, August 31, 1951.

Gardner, R. (1952). "First Lady" of the Voice of America. The New York Times (Feb 3 1952). Retrieved from ProQuest Historical Newspapers database.

History Matters (n.d.). U.S. Senate, State Department Loyalty Investigation Committee on Foreign Relations, 81st Congress; Joseph McCarthy to President Harry Truman February 11, 1950, Congressional Record, 81st Congress. Retrieved from http://historymatters.gmu.edu/d/6456. [Accessed: 12 March 2015]

Hommage. (1952, January). The Papers of Eleanor Roosevelt 1945-1962 Part I: United Nations Correspondence and Publications. Reel 10. 184. Middelburg: Roosevelt Study Center Collection.

Kuhn, R. (1995). The Media in France. London, New York: Routledge.

Listeners' Reactions to Mrs. F.D. Roosevelt's Broadcasts (1951). The Papers of Eleanor Roosevelt 1945-1962 Part I: United Nations Correspondence and Publications. Reel 10. 660-661. Middelburg: Roosevelt Study Center Collection.

Memorandum. (1952, January 5). The Papers of Eleanor Roosevelt 1945-1962 Part I: United Nations Correspondence and Publications. Reel 10. 584. Middelburg: Roosevelt Study Center Collection.

Pirsein, R. W. (1979). The Voice of America. A history of the International Broadcasting Activities of the United States Government 1940-1962. New York: Arno Press.

Press Release No. 1295. (1951, November 16). United States Delegation to The General Assembly. The Papers of Eleanor Roosevelt 1945-1962 Part I: United Nations Correspondence and Publications. Reel 26. 522-543. Middelburg: Roosevelt Study Center Collection.

Rotherbuhler, E., and McCourt, T. (2002). Radio Redefines Itself, 1947-1962. In M. Hilmes, and J. Loviglio (Eds.), Radio Reader. Essays in the Cultural History of Radio (pp. 367-387). New York, London: Routledge.

Silva Rhetoricae (n.d.). Brigham Young University. Retrieved from http://rhetoric.byu.edu/. [Accessed 9 March 2015]

Task Force - Celebrating Eleanor Roosevelt (2008). Eleanor Roosevelt and the Universal Declaration of Human Rights. Retrieved from FDR Library: http://www.fdrlibrary.marist.edu/library/pdfs/sears.pdf. [Accessed: 12 March 2015]

Wamboldt, H. J. (1952). A descriptive and analytical study of the speaking career of Anna Eleanor Roosevelt. Los Angeles: University of Southern California.

Wiesen-Cook, B. (1992). Eleanor Roosevelt. Vol 1: 1884-1933. New York: Penguin. 